\title{
- MJERENJE MORFOLOŠKE PRODUKTIVNOSTI AKRONIMA U ENGLESKOM JEZIKU - ONOMASIOLOŠKI PRISTUP
}

\author{
MAJA M. ŽARKOVIÍ ${ }^{1}$ \\ Univerzitet u Istočnom Sarajevu, \\ Bosna i Hercegovina
}

Danas u izračunavanju morfološke produktivnosti tvorbenih procesa

dominiraju Bajenove formule, ali uz njih i samo jedan tvorbeni proces - derivacija. Derivacija jeste primarni tvorbeni proces koji svakodnevno obogaćuje rječnik engleskog jezika, ali ne i jedini. Izračunavanje morfološke produktivnosti se smatra kompleksnim lingvističkim fenomenom što znači da proučavanje samo derivacije nije dovoljno kako bi ovaj fenomen u lingvistici bio što jasniji. Onomasiološki pristup kreće od značenja ka formi i u centar stavlja govornika i jezičku zajednicu. Pravila tvorbe koja dovode do nastajanja što više različitih semantičkih koncepata se mogu klasifikovati kao produktivna. Cilj našeg rada jeste da koristeći onomasiološki pristup koji je predložio Štekauer analiziramo interakciju koju diktiraju pravila tvorbe jednog sekundarnog tvorbenog procesa kao što je akronimija prije nego što nastane finalni izraz kako bismo predstavili frekventne i govornicima korisne načine imenovanja. Novinski, književni, stručni i televizijski registar kao i statistički i deskriptivno-analitički metod su potvrdili našu početnu hipotezu da će govornici pravila tvorbe koja diktiraju interakciju elemenata neophodnih za nastajanje akronima u engleskom jeziku koristiti za imenovanje više različitih semantičkih koncepata, što će ovaj tvorbeni proces staviti u kategoriju produktivnih.

Ključne riječi: morfološka produktivnost, onomasiološka teorija, akronimija.

\section{UVOD}

Pitanje morfološke produktivnost postalo je interesantno u savremenim lingvističkim istraživanjima jer se do tada leksička istraživanja obično nisu smatrala toliko preciznim kao sintaksička. Pojačano interesovanje lingvistike za ovaj problem

1 Kontakt podaci (Email): maja.zarkovic@ffuis.edu.ba 
dovodi do konstantnog oblikovanja i mijenjanja samog termina što ga čini kako interesantnim tako i izuzetno delikatnim za istraživanje (Bauer 2005: 315-316). Upravo zato i ne čudi što definicija koja ovaj pojam definiše na šest različitih načina jeste jedna od najsveobuhvatnijih jer tako vidimo da se morfološka produktivnost bavi frekventnošću nastalih riječi, frekventnošću osnova, odnosom izmeđi riječi koje su zaista nastale i riječi koje bi mogle nastati kao rezultat nekog tvorbenog procesa, mogućnošću nastajanja novih riječi, vjerovatnoćom nastajanja novih riječi i brojem novih riječi u određenom, specifičnom vremenskom periodu (Rainer 1987, kod Bauer 2004: 25).

Pojačano interesovanje lingvistike, međutim, nije usmjereno samo na adekvatno definisanje morfološke produktivnosti nego i na pronalaženje adekvatnih mjera za izračunavanje produktivnosti. U početku, lingvisti su kvalitativno pokušavali da postignu takav cilj, ali im tek kvantitativni pristup omogućava takvo nešto. Najznačajniji predstavnik kvantitativnog pristupa izračunavanja jeste Bajen (Baayen) koji je uvođenjem svoje dvije formule $(1992,1993)$ postao nezaobilazan u svim savremenim istraživanjima koja i dalje pokušavaju da daju odgovor na pitanje morfološke produktivnosti tvorbenih procesa u engleskom jeziku (Baayen 1994; Baayen i Renouf 1996; Baayen i Neijt 1997; Plag, Dalton-Puffer i Baayen 1999; Hay i Baayen 2002; Hay i Baayen 2003; Plag 2003; Fernandez-Dominguez, Diaz-Negrillo i Štekauer 2007).

Iako efikasne, dominante i nezaobilazne, Bajenove formule se pojavljuju samo prilikom izračunavanja morfološke produktivnosti derivacije koja jeste jedan od najznačajnijih tvorbenih procesa, ali sigurno ne i jedini. Razlog zašto se najviše piše o derivaciji jeste što jedino derivacija može da ponudi komponente neophodne da bi Bajenove formule mogle da funkcionišu.

Kvantitativno proučavanje morfološke produktivnosti ne bi trebalo da se svede samo na proučavanje derivacije jer rječnik engleskog jezika svakodnevno obogaćuju i drugi tvorbeni procesi. Upravo zbog toga, sve više pažnje se posvećuje samim pravilima tvorbe u proučavanju morfološke produktivnosti, što nas dovodi do onomasiološkog pristupa. Primjenjivost i efikasnost ovog pristupa prilikom izračunavanja produktivnosti jednog sekundarnog tvorbenog procesa kao što je akronimija jeste predmet istraživanja u našem radu. U onomasiološkoj teoriji se kreće od značenja ka formi, suština tvorbenih procesa jeste u nastajanju riječi a ne njihovom razlaganju na sastavne dijelove i od vitalnog značaja jeste kognitivni aspekt, tj. govornik i jezička zajednica (Grzega 2005). Interakcija različitih elemenata je u osnovi svih pravila tvorbe pa je proučavanje te interakcije prije nego što nastane finalni izraz i predstavljanje frekventnih i govornicima korisnih načina imenovanja naš osnovni cilj istraživanja. To, u našem konkretnom slučaju, znači da želimo da utvrdimo koliko su akronimi koji se izgovaraju slovo po slovo i akronimi koji se izgovaraju kao jedna riječ frekventni i korisni načini imenovanja, ali i prikažemo način interakcije riječi od kojih dobijamo takve akronime. Naša početna hipoteza jeste da će govornici pravila tvorbe koja diktiraju interakciju elemenata neophodnih za nastajanje akronima u engleskom jeziku koristiti za imenovanje više različitih semantičkih koncepata što će ovaj tvorbeni proces staviti u kategoriju produktivnih. Pri dokazivanju naše hipoteze ćemo koristiti najviše statistički metod, ali i, nezaobilazni, deskriptivno-analitički. 


\section{ONOMASIOLOŠKI MODEL MJERENJA MORFOLOŠKE PRODUKTIVNOSTI AKRONIMA}

Štekauer(Štekauer)se smatrajednim od najznačajnijih začetnika onomasiološkog pristupa. On smatra da se tvorbeni proces dešava svaki put kada govornik ima potrebu da imenuje nešto što ne postoji u leksikonu (Štekauer 2005, Štekauer, Chapman, Tomaščikova and Franko2005; Fernandez-Dominguez, Diaz-NegrilloiŠtekauer 2007). Model koji postavlja sastoji se od četiri različita nivoa na kojima se vrši imenovanje, što, u stvari, znači da postoje četiri nivoa produktivnosti: produktivnost na nivou onomasioloških tipova, tvorbenih tipova, morfoloških tipova i nivou pravila tvorbe (Štekauer, Chapman, Tomaščikova and Franko 2005: 10). Svako novo imenovanje prvo nastaje na konceptualnom nivou, gdje se ono što treba da se imenuje identifikuje i svrstava u neki semantički koncept ${ }^{2}$ (agent, instrument itd.), a poslije se pristupa identifikovanju semantičkih i morfemskih komponenti koje sačinjavaju novonastalu strukturu3 (Štekauer, Chapman, Tomaščikova and Franko 2005: 9). Nivo pravila tvorbe, koji ćemo da primjenimo u analizi naših primjera, objedinjuje nivo tvorbenih tipova i morfoloških tipova, to jeste, predstavlja nam različite tvorbene tipove koji učestvuju u formiranju istih ili različitih semantičkih koncepata. Tvorbeni tipovi ujedno imaju svoju morfološku strukturu koja se predstavlja različitim morfološkim tipovima. Nivo tvorbenih tipova kao i nivo morfoloških tipova su $100 \%$ produktivni, ali kako u formiranju jednog semantičkog koncepta možemo da pronađemo različite i tvorbene i morfološke tipove, možemo statistički da predstavimo i njihovo učešće. Na primjer, semantički koncept agenta na nivou tvorbenih tipova može da bude analiziran na više različitih načina zato što može da se sastoji od više različitih tvorbenih tipova: [lokacija - aktivnost - agent] (street-fighter) ili [aktivnost- agent] (writer). Isti semantički koncept i na nivou morfoloških tipova može da ima više načina analize jer i ovdje možemo da imamo više različitih morfoloških tipova: bodyguard [imenica + imenica] ili novelist [imenica + sufiks -ist]. Nivo pravila tvorbe nam sumarno predstavlja učešće i tvorbenih i morfoloških tipova kako za ovaj semantički koncept tako i za bilo koji drugi koji može da se pojavi u nekoj analizi (Štekauer, Chapman, Tomaščikova and Franko 2005). Na taj način dobijamo prikaz učešća pravila tvorbe za isti ili različite semantičke koncepte. Frekventnije učešće određene komponente, $u$ našem slučaju, pravila tvorbe, u nastajanju što više različitih semantičkih koncepata znači ujedno i produktivnost.

Akronimija je tvorbeni proces koji je uglavnom zasnovan na ortografskim principima (Bauer 1983: 238). Definiše se kao proces u kome leksičke jedinice nastaju upotrebom početnih slova ili dijelova grupe povezanih riječi, npr. a.k.a. (also known as), radar (radio detection and ranging) (Jovanović 2008: 254-256). Akronimi mogu

2 Koncepti se definišu kao mentalne predstave koje skladište znanje o različitim kategorijama, omogućavajući nam da određene stvari podvedemo pod odgovarajuću kategoriju (Cruse 2006: 30).

3 Kognitivne lingvističke teorije naglašavaju da samo ukoliko se naglasi uloga koncepta, možemo razumjeti način na koji shvatamo značenje riječi, jer koncept obuhvata sve: od iskustva koje prolazi kroz naš senzorni sistem do emocija i različitih vrsta konteksta. Na taj način um govornika postaje neka vrsta medijatora između jezika i svijeta (Bilbija 2001: 26). 
da se izgovaraju slovo po slovo i obično predstavljaju rezultat spajanja početnih slova (BBC (British Broadcasting Corporation)), ali i kao jedna riječ ukoliko, naravno, zadovolje fonološke kriterijume engleskog jezika (laser (light amplification by stimulated emission of radiation), UNICEF (United Nations International Children's Emergency Fund)) (Adams 1973; Bauer 1983; Yule 1996; Jovanović 2008). ${ }^{4}$ Smatra se da je intenzivnija upotreba akronima počela početkom prošlog vijeka, između dva svjetska rata, kao potreba da se daju imena kako vladinim agencijama, tako i internacionalnim organizacijama (Adams 1973: 136). Danas se akronimi mnogo učestalije upotrebljavaju nego fraze od koje su nastali, što se idealno vidi u primjerima kao što su ATM (automatic teller machine) ili PIN (personal identification number), gdje se govornici više i ne trude da rekonstruišu kako je akronim nastao (Yule 1996: 68-69). Mi ćemo, kroz analizu pronađenih primjera, probati da rekonstruišemo akronime i odredimo koji način tvorbe akronima učestvuje u nastajanju što više semantičkih koncepata. Tip akronima koji bude učestvovao u nastajanju pola i više od pola pronađenih semantičkih koncepata će se smatrati produktivnim sa visokim potencijalom dok će produktivnost i srednji potencijal ostvarivati onaj tip koji bude učestvovao u nastajanju najmanje trećine do pola. Sve ispod toga će biti klasifikovano kao neproduktivno sa niskim potencijalom (Жарковић 2015).

\section{ANALIZA KORPUSA}

Naš korpus je sastavljen od primjera preuzetih iz novinskog, književnog, stručnog i televizijskog registra i čine ga primjeri akronima standardnog savremenog engleskog jezika koji je bio u upotrebi od 2009. do 2013. godine. Tabela broj 1 prikazuje naš korpus ${ }^{5}$ :

4 Nastajanje akronima kod kojih se u sastavu ne nalaze samo početna slova riječi nekih fraza vrlo je moguće i učestalo, na primjer GHOST (Global Horizontal Sounding Technique) (Bauer 1983: 238). Nešto slično je mnogo učestalije u specijalističkim tehničkim oblastima, gdje je povećana potreba davanja prostih termina za neke složene procese, pa tako u okviru kompjuterske tehnologije pronalazimo mnogo akronima sa sufiksom -ac kao uobičajenim dijelom akronima (ordvac (ordance vaariable automatic computer), radac (rapid digital automatic computing system)) (Adams 1973: 137).

5 Pogledati Literaturu za skraćenice kojima ćemo označavati izvore primjera u radu. 


\begin{tabular}{|c|c|c|c|c|}
\hline Novinski: & Književni': & Stručni?: & Televizijski: & $\begin{array}{l}\text { Broj } \\
\text { riječi }\end{array}$ \\
\hline $\begin{array}{l}2013 . \\
\text { The Guardian, } \\
\text { The Telegraph, } \\
\text { The Sun }\end{array}$ & $\begin{array}{l}\text { Groff, Lauren. } \\
\text { (2009). Delicate } \\
\text { Birds and Other } \\
\text { Stories, } \\
\text { Hayes, Sadie. } \\
\text { (2011). The } \\
\text { Start-Up. The } \\
\text { Anti-Social } \\
\text { Network, Casey, } \\
\text { Ryan. (2012). } \\
\text { What We Saw, } \\
\text { Keplinger, Kody. } \\
\text { (2013). Secrets } \\
\text { and Lies }\end{array}$ & $\begin{array}{l}\text { Moral } \\
\text { Judgement and } \\
\text { Decision Making } \\
\text { (2009), } \\
\text { The Handbook } \\
\text { of Evolutionary } \\
\text { Economic } \\
\text { Geography } \\
\text { (2010), } \\
\text { NETWORK } \\
\text { GEEKS: How } \\
\text { They Built the } \\
\text { Internet (2013) }\end{array}$ & $\begin{array}{l}\text { House (2012), } \\
\text { The Vampire } \\
\text { Diaries (2010- } \\
\text { 2011), } \\
\text { Two and a Half } \\
\text { Men (2009), } \\
\text { The Big Bang } \\
\text { Theory (2011) }\end{array}$ & \\
\hline 100590 & 187040 & 99228 & 121376 & 508234 \\
\hline
\end{tabular}

Tabela 1. Korpus

U korpusu pronalazimo ukupno 150 akronima, 144 primjera imenica i 6 pridjeva. Najviše pronađenih primjera nastalo je kao rezultat imenovanja gdje se svako početno slovo izgovara posebno (ukupno 126 primjera), nešto manja grupa primjera jesu akronimi koji imaju status riječi (ukupno 24 primjera).

Analizu započinjemo sa akronimima imenicama. Ova vrsta akronima je u našem korpusu ostvarila ukupno 12 različitih semantičkih koncepata: instrument (27 primjera), institucija (26), agent (26), lokacija (20), stanje (17), aktivnost (15), supstanca (3), rezultat (3), vrijeme (2), kvantitet (2), objekat (2) i kvalitet (1).

Naša analiza će predstaviti interakciju različitih elemenata na nivou tvorebenih i morfoloških tipova kako bismo stekli uvid u interakciju različitih elemenata pri formiranju ne samo akronima nego i različitih sematičkih koncepata. Semantički koncept instrumenta predstavlja oba načina nastajanja akronima u našem istraživanju:

\footnotetext{
6 Pogledati Literaturu za više detalja o pričama i književnom registru.

7 Pogledati Literaturu za više detalja o člancima i stručnom registru.

8 Pogledati Literaturu za više detalja o odabranim epizodama i televizijskom registru.
} 


\begin{tabular}{|c|c|c|c|}
\hline $\begin{array}{c}\text { Načini nastajanja } \\
\text { akronima: }\end{array}$ & $\begin{array}{c}\text { Tvorbeni tipovi i morfološki } \\
\text { tipovi: }\end{array}$ & $\begin{array}{c}\text { Укупан } \\
\text { број (27) }\end{array}$ & $\begin{array}{c}\text { Продуктивност } \\
100 \%\end{array}$ \\
\hline $\begin{array}{c}\text { Akronim gdje } \\
\text { se svako slovo } \\
\text { posebno izgovara }\end{array}$ & $\begin{array}{c}\text { agent + kvalitet + aktivnost + } \\
\text { instrument } \\
\text { imenica + sufiks + glagol + } \\
\text { sufiks } \\
\text { PC (personal computer) (NG 58) }\end{array}$ & 19 & $70,37037 \%$ \\
\hline Akronim kao riječ & $\begin{array}{c}\text { kvalitet + aktivnost + } \\
\text { mogućnost } \\
\text { pridjev + imenica + imenica } \\
\text { RAM (random access memory) } \\
\text { (GEEK 47) }\end{array}$ & 8 & $29,62962 \%$ \\
\hline
\end{tabular}

Tabela 2. Produktivnost semantičkog koncepta instrumenta kod akronima imenica

Sematički koncept institucije nam takođe pokazuje da akronimi imenice mogu da nastanu uz primjenu oba načina imenovanja:

\begin{tabular}{|c|c|c|c|}
\hline $\begin{array}{c}\text { Načini nastajanja } \\
\text { akronima: }\end{array}$ & $\begin{array}{c}\text { Tvorbeni tipovi i morfološki } \\
\text { tipovi: }\end{array}$ & $\begin{array}{c}\text { Укупан } \\
\text { број (26) }\end{array}$ & $\begin{array}{c}\text { Продуктивност } \\
100 \%\end{array}$ \\
\hline $\begin{array}{c}\text { Akronim gdje } \\
\text { se svako slovo } \\
\text { posebno izgovara }\end{array}$ & $\begin{array}{c}\text { Iokacija + lokacija + lokacija } \\
\text { pridjev + imenica + imenica } \\
\text { FCO (Foreign and Commonwealth } \\
\text { Office) (TG 27.4) }\end{array}$ & 20 & $76,92307 \%$ \\
\hline Akronim kao riječ & $\begin{array}{c}\text { Iokacija + stanje + aktivnost + } \\
\text { aktivnost } \\
\text { imenica + imenica + glagol + } \\
\text { sufiks } \\
\text { W.H.O. (World Health } \\
\text { Organization) } \\
\text { (H S8 E20) }\end{array}$ & 6 & $23,07692 \%$ \\
& & & \\
\hline
\end{tabular}

Tabela 3. Produktivnost semantičkog koncepta institucije kod akronima imenica

Značenje agenta je podjednako zastupljeno kao i značenje institucije i u njegovom formiranju pronalazimo oba načina nastajanja akronima:

\begin{tabular}{|c|c|c|c|}
\hline $\begin{array}{c}\text { Načini nastajanja } \\
\text { akronima: }\end{array}$ & $\begin{array}{c}\text { Tvorbeni tipovi i morfološki } \\
\text { tipovi: }\end{array}$ & $\begin{array}{c}\text { Укупан } \\
\text { број (26) }\end{array}$ & $\begin{array}{c}\text { Продуктивност } \\
100 \%\end{array}$ \\
\hline Akronim gdje & $\begin{array}{c}\text { kvantitet + kvalitet + agent } \\
\text { se svako slovo } \\
\text { prilog + pridjev + imenica } \\
\text { posebno izgovara (very important person ) (TS } \\
\text { 29.4) }\end{array}$ & 20 & $76,92307 \%$ \\
& \multicolumn{2}{|c|}{} & \\
\hline
\end{tabular}




\begin{tabular}{|c|c|c|c|}
\hline Akronim kao riječ & $\begin{array}{c}\text { agent + lokacija + aktivnost } \\
\text { imenica + prijedlog + imenica } \\
\text { cop (constable on patrol) (ASN } \\
10)\end{array}$ & 6 & $23,07692 \%$ \\
\hline
\end{tabular}

Tabela 4. Produktivnost semantičkog koncepta agenta kod akronima imenica

U korpusu pronalazimo i znatan broj primjera akronima koji označavaju lokaciju i po prvi put samo jedan način formiranja akronima:

\begin{tabular}{|c|c|c|c|}
\hline $\begin{array}{l}\text { Načini nastajanja } \\
\text { akronima: }\end{array}$ & $\begin{array}{l}\text { Tvorbeni tipovi i morfološki } \\
\text { tipovi: }\end{array}$ & $\begin{array}{c}\text { Укупан } \\
\text { број (20) }\end{array}$ & $\begin{array}{c}\text { Продуктивност } \\
100 \% \\
\end{array}$ \\
\hline $\begin{array}{c}\text { Akronim gdje } \\
\text { se svako slovo } \\
\text { posebno izgovara }\end{array}$ & $\begin{array}{c}\text { aktivnost + aktivnost + aktivnost } \\
+ \text { aktivnost + lokacija + lokacija } \\
\text { glagol + sufiks + glagol + sufiks + } \\
\text { imenica + imenica } \\
\text { GCHQ (Government } \\
\text { Communications Headquarters) } \\
\text { (NG 23) }\end{array}$ & 20 & $100 \%$ \\
\hline
\end{tabular}

Tabela 5. Produktivnost semantičkog koncepta lokacije kod akronima imenica

Akronimi imenice označavaju i različita stanja i nastaju na oba načina u našem korpusu:

\begin{tabular}{|c|c|c|c|}
\hline $\begin{array}{c}\text { Načini nastajanja } \\
\text { akronima: }\end{array}$ & $\begin{array}{c}\text { Tvorbeni tipovi i morfološki } \\
\text { tipovi: }\end{array}$ & $\begin{array}{c}\text { Укупан } \\
\text { број (17) }\end{array}$ & $\begin{array}{c}\text { Продуктивност } \\
100 \%\end{array}$ \\
\hline $\begin{array}{c}\text { Akronim gdje } \\
\text { se svako slovo } \\
\text { posebno izgovara }\end{array}$ & $\begin{array}{c}\text { vrijeme + stanje + stanje + stanje } \\
\text { + stanje } \\
\text { prefiks + imenica + sufiks + } \\
\text { imenica + imenica } \\
\text { PTSD (posttraumatic stress } \\
\text { disorder) } \\
\text { (H S8 E18) }\end{array}$ & 16 & $94,11764 \%$ \\
\hline Akronim kao riječ & $\begin{array}{c}\text { aktivnost + aktivnost + stanje + } \\
\text { stanje + stanje + stanje } \\
\text { glagol + sufiks + pridjev + } \\
\text { pridjev + sufiks + imenica } \\
\text { AIDS (acquired immunodeficiency } \\
\text { syndrome) (DBB 55) }\end{array}$ & 1 & $5,88235 \%$ \\
\hline
\end{tabular}

Tabela 6. Produktivnost semantičkog koncepta stanja kod akronima imenica 
I semantički koncept aktivnosti pokazuje akronime koji nastaju na oba načina:

\begin{tabular}{|c|c|c|c|}
\hline $\begin{array}{l}\text { Načini nastajanja } \\
\text { akronima: }\end{array}$ & $\begin{array}{l}\text { Tvorbeni tipovi i morfološki } \\
\text { tipovi: }\end{array}$ & $\begin{array}{l}\text { Укупан } \\
\text { број (15) }\end{array}$ & $\begin{array}{c}\text { Продуктивност } \\
100 \%\end{array}$ \\
\hline $\begin{array}{c}\text { Akronim gdje } \\
\text { se svako slovo } \\
\text { posebno izgovara }\end{array}$ & $\begin{array}{c}\text { aktivnost + objekat + agent } \\
\text { glagol + objekatska zamjenica + } \\
\text { povratna zamjenica } \\
\text { DIY (do-it-yourself) (DT 27.4) }\end{array}$ & 13 & $86,66666 \%$ \\
\hline Akronim kao riječ & $\begin{array}{l}\text { supstanca + aktivnost + } \\
\text { aktivnost + aktivnost } \\
\text { imenica + glagol + sufiks + } \\
\text { imenica } \\
\text { PET (positron emission } \\
\text { tomography) } \\
\text { (HS8 E21) }\end{array}$ & 2 & $13,33333 \%$ \\
\hline
\end{tabular}

Tabela 7. Produktivnost semantičkog koncepta aktivnost kod akronima imenica

Našu analizu nastavljamo sa semantičkim konceptima koji koriste samo jedan način formiranja akronima. Takvi koncepti su supstanca:

\begin{tabular}{|c|c|c|c|}
\hline $\begin{array}{c}\text { Načini nastajanja } \\
\text { akronima: }\end{array}$ & $\begin{array}{c}\text { Tvorbeni tipovi i morfološki } \\
\text { tipovi: }\end{array}$ & $\begin{array}{c}\text { Укупан } \\
\text { број (3) }\end{array}$ & $\begin{array}{c}\text { Продуктивност } \\
100 \%\end{array}$ \\
\hline $\begin{array}{c}\text { Akronim gdje } \\
\text { se svako slovo } \\
\text { posebno izgovara }\end{array}$ & $\begin{array}{c}\text { boja + supstanca + supstanca } \\
\text { pridjev + imenica + imenica } \\
R B C(\text { red blood cells) (H S8 E21) }\end{array}$ & 3 & $100 \%$ \\
\hline
\end{tabular}

Tabela 8. Produktivnost semantičkog koncepta supstance kod akronima imenica

rezultat:

\begin{tabular}{|c|c|c|c|}
\hline $\begin{array}{c}\text { Načini nastajanja } \\
\text { akronima: }\end{array}$ & $\begin{array}{c}\text { Tvorbeni tipovi i morfološki } \\
\text { tipovi: }\end{array}$ & $\begin{array}{c}\text { Укупан } \\
\text { број (3) }\end{array}$ & $\begin{array}{c}\text { Продуктивност } \\
100 \%\end{array}$ \\
\hline $\begin{array}{c}\text { Akronim gdje } \\
\text { se svako slovo } \\
\text { posebno izgovara }\end{array}$ & $\begin{array}{c}\text { kvalitet + kvalitet + kvantitet } \\
\text { pridjev + sufiks + imenica } \\
\text { IQ (intelligence quotient) (NG 27) }\end{array}$ & 3 & $100 \%$ \\
\hline
\end{tabular}

Tabela 9. Produktivnost semantičkog koncepta rezultata kod akronima imenica

vrijeme:

\begin{tabular}{|c|c|c|c|}
\hline $\begin{array}{c}\text { Načini nastajanja } \\
\text { akronima: }\end{array}$ & $\begin{array}{c}\text { Tvorbeni tipovi i morfološki } \\
\text { tipovi: }\end{array}$ & $\begin{array}{c}\text { Укупан } \\
\text { број (2) }\end{array}$ & $\begin{array}{c}\text { Продуктивност } \\
100 \%\end{array}$ \\
\hline $\begin{array}{c}\text { Akronim gdje } \\
\text { se svako slovo } \\
\text { posebno izgovara }\end{array}$ & $\begin{array}{c}\text { vrijeme + vrijeme } \\
\text { prijedlog + imenica } \\
\text { am (ante meridiem - before noon) } \\
\text { (DT 13.6) }\end{array}$ & 2 & $100 \%$ \\
\hline
\end{tabular}


Tabela 10. Produktivnost semantičkog koncepta vremena kod akronima imenica

kvantitet:

\begin{tabular}{|c|c|c|c|}
\hline $\begin{array}{c}\text { Načini nastajanja } \\
\text { akronima: }\end{array}$ & Tvorbeni tipovi i morfološki tipovi: & $\begin{array}{c}\text { Укупан } \\
\text { број (2) }\end{array}$ & $\begin{array}{c}\text { Продуктивност } \\
100 \%\end{array}$ \\
\hline $\begin{array}{c}\text { Akronim gdje } \\
\text { se svako slovo } \\
\text { posebno izgovara }\end{array}$ & $\begin{array}{c}\text { kvantitet + kvantitet } \\
\text { pridjev + imenica } \\
\text { (C (cubic centimetre) (H S8 E20) }\end{array}$ & 2 & $100 \%$ \\
\hline
\end{tabular}

Tabela 11. Produktivnost semantičkog koncepta kvantiteta kod akronima imenica

objekat:

\begin{tabular}{|c|c|c|c|}
\hline $\begin{array}{c}\text { Načini nastajanja } \\
\text { akronima: }\end{array}$ & Tvorbeni tipovi i morfološki tipovi: & $\begin{array}{c}\text { Укупан } \\
\text { број (2) }\end{array}$ & $\begin{array}{c}\text { Продуктивност } \\
100 \%\end{array}$ \\
\hline $\begin{array}{c}\text { Akronim gdje } \\
\text { se svako slovo } \\
\text { posebno izgovara }\end{array}$ & $\begin{array}{c}\text { objekat } \\
\text { imenica }\end{array}$ & 2 & $100 \%$ \\
\hline
\end{tabular}

Tabela 12. Produktivnost semantičkog koncepta objekta kod akronima imenica

i kvalitet:

\begin{tabular}{|c|c|c|c|}
\hline $\begin{array}{c}\text { Načini nastajanja } \\
\text { akronima: }\end{array}$ & Tvorbeni tipovi i morfološki tipovi: & $\begin{array}{c}\text { Укупан } \\
\text { број (1) }\end{array}$ & $\begin{array}{c}\text { Продуктивност } \\
100 \%\end{array}$ \\
\hline $\begin{array}{c}\text { Akronim gdje } \\
\text { se svako slovo } \\
\text { posebno izgovara }\end{array}$ & $\begin{array}{c}\text { agent + supstanca } \\
\text { imenica + imenica } \\
B S \text { (bullshit) (H S8 E18) }\end{array}$ & 1 & $100 \%$ \\
\hline
\end{tabular}

Tabela 13. Produktivnost semantičkog koncepta kvaliteta kod akronima imenica

Nakon analiziranja pronađenih primjera akronima imenica možemo da uočimo da je način nastanka akronima gdje dolazi do spajanja početnih slova ili elemenata jedne, dviju ili više međusobno povezanih riječi, a da se pri tome ta slova posebno izgovaraju, izuzetno produktivan i pokazuje visok potencijal. Ovakav zaljučak potkrepljuju naši primjeri koji pokazuju da učestvuje u nastajanju svih dvanaest semantičkih koncepata. Drugi način nastajanja akronima, gdje takođe dolazi do spajanja početnih slova ili elemenata jedne, dviju ili više riječi, ali gdje akronim ima status riječi i tako se i izgovara, takođe je produktivan, ali ostvaruje srednii potencijal jer učestvuje u formiranju manje od pola pronađenih semantičkih konepata (ukupno pet).

Analizu nastavljamo sa akronimima pridjevima koji u našem korpusu ostvaruju tri semantička koncepta (kvalitet, lokacija i agent) i samo jedan način formiranja akronima učestvuje u svakom od pronađenih koncepata. Započinjemo sa značenjem kvaliteta: 


\begin{tabular}{|c|c|c|c|}
\hline $\begin{array}{c}\text { Načini nastajanja } \\
\text { akronima: }\end{array}$ & Tvorbeni tipovi i morfološki tipovi: & $\begin{array}{c}\text { Укупан } \\
\text { број (4) }\end{array}$ & $\begin{array}{c}\text { Продуктивност } \\
100 \%\end{array}$ \\
\hline $\begin{array}{c}\text { Akronim gdje } \\
\text { se svako slovo } \\
\text { posebno izgovara }\end{array}$ & $\begin{array}{c}\text { agent + kvalitet } \\
\text { imenica + pridjev }\end{array}$ & 4 & $100 \%$ \\
\hline JV (junior varsity) (SLPWK 6) & & \\
\hline
\end{tabular}

Tabela 14. Produktivnost semantičkog koncepta kvaliteta kod akronima pridjeva

Čest akronim u medicinskom diskursu je ujedno i jedini primjer sa značenjem lokacije:

\begin{tabular}{|c|c|c|c|}
\hline $\begin{array}{c}\text { Načini nastajanja } \\
\text { akronima: }\end{array}$ & $\begin{array}{c}\text { Tvorbeni tipovi i morfološki } \\
\text { tipovi: }\end{array}$ & $\begin{array}{c}\text { Укупан } \\
\text { број (1) }\end{array}$ & $\begin{array}{c}\text { Продуктивност } \\
100 \%\end{array}$ \\
\hline Akronim gdje & lokacija + lokacija + lokacija & 1 & $100 \%$ \\
se svako slovo & prefiks + imenica + sufiks & & \\
posebno izgovara & IV (intravenous) (H S8 E19) & & \\
\hline
\end{tabular}

Tabela 15. Produktivnost semantičkog koncepta lokacije kod akronima pridjeva

Primjer akronima pridjeva koji ostvaruje značenje agenta jeste i jedini primjer pridjeva koji je akronim sa statusom riječi. Kod ovog primjera nije došlo do spajanja početnih slova dvije ili više riječi, nego do spajanja tri početna slova jedne riječi, što bi se moglo klasifikovati i kao skraćivanje, ali autori zbog tačke koja se uvijek piše iza ovog akronima sa sigurnošću ovaj primjer vide kao akronim (Plag 2003: 161):

\begin{tabular}{|c|c|c|c|}
\hline $\begin{array}{c}\text { Načini nastajanja } \\
\text { akronima: }\end{array}$ & $\begin{array}{c}\text { Tvorbeni tipovi i morfološki } \\
\text { tipovi: }\end{array}$ & $\begin{array}{c}\text { Укупан } \\
\text { број (1) }\end{array}$ & $\begin{array}{c}\text { Продуктивност } \\
100 \%\end{array}$ \\
\hline Akronim kao riječ & $\begin{array}{c}\text { aktivnost + aktivnost } \\
\text { glagol + sufiks } \\
\text { Inc. (incorporated) (SLPWK 31) }\end{array}$ & 1 & $100 \%$ \\
\hline
\end{tabular}

Tabela 16. Produktivnost semantičkog koncepta agenta kod akronima pridjeva

Analiza pronađenih akronima pridjeva pokazuje nam da su načini gdje dolazi do spajanja početnih slova ili elemenata riječi, a da se pri tome ta slova posebno izgovaraju da bi akronim mogao nešto da imenuje ili gdje akronim ima status riječi i učestvuje u imenovanju dva načina nastajanja pridjeva kao akronima. Prvi način moramo da svrstamo u grupu produktivnih jer od ukupno tri pronađena semantička koncepta učestvuje u formiranju dva, što je i indikator njegovog visokog potencijala, dok je akronim pridjev koji ima status riječi takođe produktivan, ali ostvaruje srednji potencijal jer učestvuje u nastajanju samo jednog semantičkog koncepta. 


\section{ZAKLJUČAK}

Na kraju naše analize akronimije možemo da zaključimo da je ovaj tvorbeni proces izuzetno prisutan u različitim vrstama tekstova. Čini se, prema podacima koje smo dobili nakon analize primjera i imenica i pridjeva, da govornici podjednako koriste oba načina nastajanja akronima u procesu imenovanja. Kod imenica produktivnost i visok potencijal pokazuju akronimi kod kojih se početna slova riječi od kojih su nastali posebno izgovaraju, dok akronimi koji se izgovaraju kao jedan riječ spadaju u grupu produktivnih, ali ostvaruju srednji potencijal. Ovakvi rezultati pokazuju lingivstičku svijest govornika o značenju sastavnih dijelova i upotrebu za različite svrhe imenovanja. Kod pridjeva produktivnost i visok potencijal pokazuje način u okviru koga se početna slova nastalog akronima posebno izgovaraju, ali produktivnost sa srednjim potencijalom pokazuje i način gdje dobijamo akronim sa statusom riječi. Postojanje oba načina za mali broj primjera doprinosi tvrdnji da se radi o prisutnom tvorbenom procesu koji ukazuje na postojanje spremnosti govornika da ih, manje ili više, koriste kako bi dobili različite semantičke koncepte. I imenice i pridjevi pokazuju da aktivnost upotrebe različitih načina nastajanja akronima u nastajanju različitih semantičkih koncepata jeste, ujedno, i pokazatelj njihove produktivnosti i potencijala. Na ovaj način smo postigli cilj koji smo postavili na samom početku rada, ali i potvrdili našu početnu hipotezu. Možemo samo da zaključimo da prilikom nastajanja akronima govornici vide oba mehanizma kao pogodne i korisne za potrebe imenovanja, pa onda i ne čudi sve veće prisustvo akronima neformalne konotacije, koji se često mogu vidjeti na različitim društvenim mrežama. Analiza akronima koji se pojavljuju na društvenim mrežama mogla bi da bude neka nova tema u istraživanju ovog tvorbenog procesa jer vjerujemo da bi takav korpus doveo do mnogih primjera za koje bi se slobodno moglo reći da predstavljaju neki potpuno nov jezik i način izražavanja.

\section{LITERATURA}

Adams, V. 1973. An Introduction to Modern English Word-formation. Whitstable: Whitstable Litho Itd.

Baayen, R.H. 1992. Quantitative aspects of morphological productivity. U: G.E Booij i J. Van Marle (ur.) Yearbook of Morphology 1991. Dordrecht: Kluwer, 109-149.

Baayen, R.H. 1993. On frequency, transparency and productivity. U: G.E Booij i J. Van Marle (ur.) Yearbook of Morphology 1992. Dordrecht: Kluwer, 181-208.

Baayen, R.H. 1994. Derivational Productivity and Text Typology. U:Journal of Quantitative Linguistics 1. [Internet]. Dostupno na: www.ualberta.ca/ baayen/ [10.1.2013].

Baayen, R.H. i Neijt, A. 1997. Productivity in context: a case study of a Dutch suffix. U: Linguistics 35. [Internet]. Dostupno na: www.ualberta.ca/ baayen/ [10.1.2013].

Baayen, R.H. i Renouf, A. 1996. Chronicling The Times: productive lexical innovationsin an English newspaper. U: Language 72. [Internet]. Dostupno na: www.ualberta. ca/ baayen/ [10.1.2013].

Bauer, L. 1983. English Word-formation. Cambridge: CUP.

Bauer, L. 2004. Morphological Productivity. Cambridge: CUP. 
Bauer, L. 2005. Productivity: Theories. U: P. Štekauer i R. Lieber (ur.) The Handbook of Word-Formation. Netherlands: Springer, 315-334.

Bilbija, S. 2001. Introducing Semantics. Banja Luka: Komunikološki fakultet.

Cruse, A. 2006. A Glossary of Semantics and Pragmatics. Edinburgh: Edinburgh UP.

Fernandez-Dominguez, J., Diaz-Negrillo, A. i Štekauer, P. 2007. How is Low Productivity Measured?. U: Atlantis. [Internet]. Dostupno na: www. atlantisjournal.org/ archive/29.1./2007 fernandez_diaz_stakauer.pdf [10.1.2013].

Grzega, J. 2005. Comments on Pavol Štekauer's Onomasiological Approach to WordFormation. U: SKASE Journal of Theoretical Linguistics 2.2, 76-81. [Internet]. Dostupno na: http://www.joachim-grzega.de/publ-e.htm [10.2.2014].

Hay, J.i Baayen, H. 2002. Parsing and Productivity. U: G.E Booij i J. Van Marle (ur.) Yearbook of Morphology 2001. Dordrecht: Kluwer Academic Publishers. [Internet]. Dostupno na: http://www.sfs.uni-tuebingen.de/ hbaayen/publications.html [20.1.2013].

Hay, J. i Baayen, R.H. 2003. Phonotactics, pasing and productivity. U: Revista di Linguistica 15.1. [Internet]. Dostupno na: www.ualberta.ca/ baayen/ [10.1.2013.]

Jovanović, V.ž. 2008. English Morphology. A Coursebook. Niš: Filozofski fakultet Niš.

Plag, I. 2003. Word-Formation in English. Cambridge: CUP.

Plag, I., Dalton-Puffer, C. i Baayen, R. H. 1999. Productivity and register. U: Journal of English Language and Linguistics 3. [Internet]. Dostupno na: www.ualberta. ca/ baayen/ [10.1.2013].

Štekauer, P. 2005. Onomasiological Approach to Word Formation. U: P. Štekauer i R. Lieber (ur.) The Handbook of Word-Formation. Netherlands: Springer, 207-232.

Štekauer, P., Chapman, D., Tomaščikova, S. and Franko, Š. 2005. Word-formation as creativity within productivity constraints: sociolinguistic evidence. U: Onomasiology Online 6, 1-55. [Internet]. Dostupno na:

http://www1.ku-eichstaett.de/SLF/EngluVgISW/stekauer1051.pdf [20.3.2014].

Yule, G. 1996. The study of language. Second Edition. Cambridge: Cambridge University Press.

Жарковић, M.2015. Produktivnost procesa u tvorbi imenica i pridjeva u engleskom jeziku. Filozofski fakultet Univerziteta u Istočnom Sarajevu. Neobjavljena doktorska disertacija.

Korpus:

Novinski registar [preuzeto u periodu od aprila do avgusta 2013. godine]:

www.theguardian.co.uk. (TG)

www.telegraph.co.uk(DT)

www.thesun.co.uk (TS)

Književni registar [dostupno na: http://www.freebookspot.es/, april 2013. godine]:

Groff, L. 2009. Delicate Birds and Other Stories. Hyperion

Lucky Chow Fun (DBLCF), L.DeBard and Aliette (DBLDA), Majorette (DBM), Blythe (DBB), The

Wife of the Dictator (DBTWD), Watershed (DBW), Sir Fleeting (DBSF), Fugue (DBF),

Delicate Edible Birds (DBDEB)

Hayes, S. 2011. The Start-Up.The Anti-Social Network. Backlit Fiction (ASN)

Casey, R. 2012. What We Saw. Higher Bank Books. Amazon Kindle Edition (WWS)

Keplinger, K. 2013. Secrets and Lies. New York: Poppy, Hachette Book Group 


\section{People Worth Knowing (SLPWK)}

Stručni registar [dostupno na: http://www.freebookspot.es/, jun 2013. godine]:

Ginges, J. i Atran, S. 2009. Noninstrumental Reasoning over Sacred Values: An Indonesian Case Study. U: D. Bartels, C. Bauman, L. Skitka i D. Medin (ur.) Moral Judgement and Decision Making. San Diego: Eslevier, 193-206. (ICS)

Bilz, K. i Nadler, J. 2009. Law, Psychology, and Morality. U: D. Bartels, C. Bauman, L. Skitka i D. Medin (ur.) Moral Judgement and Decision Making. San Diego: Eslevier, 101-131. $(L P M)$

Connolly, T. i Hardman, D. 2009. "Fools Rush In": A JDM Perspective on the Role of Emotions in Decisions, Moral and Otherwise. U: D. Bartels, C. Bauman, L. Skitka i D. Medin (ur.) Moral Judgement and Decision Making. San Diego: Eslevier, 275-306. (FRI)

Boschma, R. i Martin, R. 2010. The aims and scope of evolutionary economic geography. U: R. Boschma i R. Martin (ur.) The Handbook of Evolutionary Economic Geography. Cheltenham, UK: Edward Elgar Publishing Limited, 3-39. (AAS)

Stam, E. 2010. Entrepreneurship, evolution and geography. U: R. Boschma i R. Martin (ur.) The Handbook of Evolutionary Economic Geography. Cheltenham, UK: Edward Elgar Publishing Limited, 139-161. (EEG)

Hassink, R. 2010. Locked in decline? On the role of regional lock- ins in old industrial areas. U: R. Boschma i R. Martin (ur.) The Handbook of Evolutionary Economic Geography. Cheltenham, UK: Edward Elgar Publishing Limited, 450-468. (LID)

Carpenter, B. E. 2013. NETWORK GEEKS: How They Built the Internet. New York: Copernicus Books Springer Science+Business Media, 9-79. (NG)

Televizijski registar [preuzeto u aprilu 2013. godine]:

HOUSE (2012), "Body \& Soul" (H S8 E18), "The (-Word" (H S8 E19), "Post Mortem" (H S8 E20), "Holding On" (H S8 E21), "Everybody Dies" (H S8 E22), dostupno na: http:// clinic-duty.livejournal.com/

THE VAMPIRE DIARIES (2010-2011), "Kill or Be Killed" (VD S2 E5), "Masquerade" (VD S2 E7), "The House Guest" (VD S2 E16), "Klaus" " (VD S2 E19), "As I Lay Dying" (VD S2 E22), dostupnp na: http://vampirediaries.wikia.com/wiki/Season_Two

TWO AND A HALF MEN (2009), "818-jkIpuzo" (TAHM S7 E1), "Whipped Unto the Third Generation" (TAHM S7 E2), "Mmm, fish. Yum." (TAHM S7 E3), "Laxative Tester, Horse Inseminator" (TAHM S7 E4), "For the Sake of the Child" (TAHM S7 E5), "Give Me Your Thumb" (TAHM S7 E6), "Untainted by Filth" (TAHM S7 E7), "Gorp. Fnark. Schmegle." (TAHM S7 E8), "Captain Terry's Spray-0n Hair" (TAHM S7 E9), "That's Why They Call It Ball Room" (TAHM S7 E10), dostupno na: http://torrentz.eu/

THE BIG BANG THEORY (2011), "The Skank Reflex Analysis" (BBT S5 E1), "The Infestation Hypothesis" (BBT S5 E2), "The Pulled Groin Extrapolation" (BBT S5 E3), "The Wiggly Finger Catalyst" (BBT S5 E4), "The Russian Rocket Reaction" (BBT S5E5), "The Rhinitis Revelation" (BBT S5 E6), "The Good Guy Fluctuation" (BBT S5 E7), "The Isolation Permutation" (BBT S5 E8), "The Ornithophobia Diffusion" (BBT S5 E9), "The Flaming Spittoon Acquisition" (BBT S5 E10), dostupnp na: http://bigbangtrans.wordpress. com/ 


\section{SUMMARY}

\section{MEASURING MORPHOLOGICAL PRODUCTIVITY OF ACRONYMY IN ENGLISH - ONOMASIOLOGICAL APPROACH}

Modern measuring of morphological productivity of word-formation processes is dominated by Baayen's formulas and together with them only one word-formation process - derivation. In order to avoid derivation-centered analysis of such a complex phenomenon as morphological productivity, more attention was directed towards word-formation rules, which led to the appearance of onomasiological theory. Onomasiologicalapproach goes from meaning towards form in word-formation analyses and focuses on a speaker and speech community. Productive word-formation processes are the ones responsible for the formation of multiple different semantic concepts. The aim of the paper is to use onomasiological approach proposed by Štekauer to analyse the interaction among word-formation rules that dominate a secondary wordformation process such as acronymy and to find frequent and speakers' useful ways of naming. Newspaper, literary, academic and television registers as well as statistic with descriptive and analytic methods confirm our inital hypothesis that speakers would use word-formation rules that dictate interaction among elements necessary for the formation of acronyms in English for forming multiple different semantic concepts, which would classify this process as productive.

KEYWORDS: morphological productivity, onomasiological theory, acronymy.

(Originalni naučni rad primljen 20.1.2017;

ispravljen 23.3.2017;

prihvaćen 20.10.2017) 